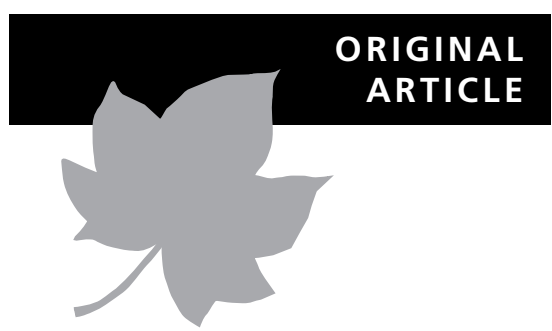

${ }^{1}$ Centre for Invasion Biology, Department of Botany and Zoology, Stellenbosch University, Matieland, 7602, South Africa, ${ }^{2}$ South African National Biodiversity Institute, Kirstenbosch National Botanical Gardens, Claremont, 7735, South Africa

${ }^{\star}$ Correspondence: Johannes J. Le Roux, Centre for Invasion Biology, Department of Botany and Zoology, Stellenbosch University, Private Bag X1, Matieland 7602, South Africa.

E-mail: jleroux@sun.ac.za; jacoleroux01@gmail.com

\section{Co-invasion of South African ecosystems by an Australian legume and its rhizobial symbionts}

Joice Ndlovu ${ }^{1}$, David M. Richardson ${ }^{1}$, John R. U. Wilson ${ }^{1,2}$ and Johannes J. Le Roux ${ }^{1 \star}$

\section{ABSTRACT}

Aim To determine and compare the taxonomic identity and diversity of root nodule and rhizospheric microbial symbionts associated with Acacia pycnantha Benth. in its native (Australian) and invasive (South African) ranges, and to establish whether these associations are general or host specific.

Location The native range of $A$. pycnantha in Australia and invasive ranges in South Africa and Western Australia.

Methods Bacteria were isolated from root nodules collected from 18 populations of $A$. pycnantha. Repetitive element polymerase chain reaction (REPPCR) fingerprinting was used to assess overall bacterial diversity and clustering. Molecular phylogenies for a subset of isolates representing major REP-PCR clades were reconstructed using maximum parsimony and Bayesian phylogenetic analyses of the nuclear 16S-23S rRNA intergenic spacer (IGS), 16S rRNA, and the symbiotic nodA genes.

Results Twelve clusters were identified from the REP-PCR analysis; 11 included isolates from both the native range in Australia and invasive range in South Africa, while one cluster comprised only Australian isolates. Six rhizobial species were found in association with A. pycnantha: Bradyrhizobium japonicum, Rhizobium gallicum, $R$. lusitanum, $R$. miluonense, $R$. multihospitium and $R$. tropici. We also identified three plant-growth promoting bacteria isolated from root nodules of A. pycnantha: Burkholderia caledonica, B. graminis and B. phytofirmans. Phylogenetic analysis of the IGS gene retrieved clades containing symbionts from both Australia and South Africa while others comprised only South African taxa, suggesting the introduction of bacterial lineages from Australia to South Africa. Our phylogeographic analysis of the nodA gene confirmed that A. pycnantha was co-introduced with its symbionts to South Africa.

Main conclusions Acacia pycnantha is a promiscuous legume, associated with at least six different rhizobial symbionts, and forms associations with plantgrowth promoting rhizosphere bacteria from the genus Burkholderia. In the invasive range of $A$. pycnantha in South Africa, nodules contained some symbionts of South African origin while other symbionts appear to have been cointroduced from Australia. Acacia pycnantha is associated with a wider suite of symbionts in its invasive than native range.

\section{Keywords}

Acacia pycnantha, Australia, biological invasions, co-introduction hypothesis, generalist, host-jumping hypothesis, mutualisms, plant growth promoters, rhizobia, South Africa. 


\section{INTRODUCTION}

The establishment of introduced plants is dependent on a variety of factors, including direct interactions with mutualists, such as pollinators and soil microbiota (Richardson et al., 2000). A growing body of evidence suggests that mutualisms between introduced plants and soil microbiota could serve as major drivers for plant invasions by improving the host's nutrient status, e.g. mycorrhizal fungi and nitrogen-fixing bacteria (rhizobia) (Reinhart \& Callaway, 2006). Similarly, other beneficial microbial associations can promote plant growth by inducing metabolic processes that counter negative feedbacks brought about by biotic and abiotic stress (Compant et al., 2008).

In general, mutualisms between invasive plants and rhizobia have been shown to increase plant biomass and to improve establishment success (Weir et al., 2004). For example, invasive Acacia longifolia in Portugal, grown in soils that were collected from sites with established legume populations (Acacia longifolia, Cytisus grandiflorus and Ulex europaeus), produced higher above-ground biomass and nodule densities than plants grown in soils collected from established Pinus pinaster stands (Rodríguez-Echeverría et al., 2009). High levels of nodulation in the invasive range are indicative of the functionality and the importance of mutualisms during spread and invasion processes (Parker, 2001). For example, in the USA, inoculation with Bradyrhizobium associated with invasive Cytisus scoparius more than doubled the average plant biomass while non-inoculated plants without root nodules had significantly lower biomass (Parker et al., 2006).

The origin(s) of nitrogen-fixing symbionts utilized by invasive legumes in their new ranges has been a subject of discussion in the invasion literature (Weir et al., 2004; Chen et al., 2005; Parker et al., 2007; Wei et al., 2009; RodríguezEcheverría, 2010; Porter et al., 2011; Rodríguez-Echeverría et al., 2011; Crisóstomo et al., 2013). Many successful invasive legumes form new mutualisms with bacteria found in the introduced environment (host-jumping hypothesis). However, symbionts can also be co-introduced with host plants, either directly as inoculants for agroforestry species (Marques et al., 2001) or indirectly by hitchhiking on introduced plant material (co-introduction hypothesis) (Weir et al., 2004; Porter et al., 2011). Some invasive legumes form a variety of different mutualisms, and can conform to both hypotheses. For example, invasive populations of Acacia longifolia and A. saligna from Portugal, Medicago polymorpha from California, USA, and Acacia decurrens from New Zealand, all recruit co-introduced bacterial symbionts (Weir et al., 2004; Rodríguez-Echeverría, 2010; Porter et al., 2011; Crisóstomo et al., 2013) and some Australian acacias are able to recruit novel symbionts when grown in non-native soils (Birnbaum et al., 2012).

This mixing of symbionts from different origins can have several consequences. In some instances, subsequent conjugation between different bacterial strains of different origins can lead to novel genetic combinations and may even enhance invasiveness (Menna \& Hungria, 2011). Alternatively, co-introduced bacteria may represent a preferred symbiotic lineage or be a different species, which can outcompete local microbiota, resulting in multiple invasions, both above and below ground (Rodríguez-Echeverría, 2010). However, different rhizobial strains usually vary in effectiveness, with co-evolved associations being the most effective. Therefore, while the ability of an invader to form mutualisms with a larger variety of rhizobia (symbiotic promiscuity) significantly improves invasion potential and success (Weir et al., 2004; Rodríguez-Echeverría et al., 2011) through host-jumping, these may not be the most effective associations. Generally, promiscuous host plants also tend to be more effective in fixing nitrogen, implying that in new environments where host plants have a choice of symbiotic partners, mutualistic interactions are likely to favour generalists and exclude specialists (Wilkinson \& Parker, 1996).

In addition to housing nitrogen-fixing bacteria, some legumes can also interact with other forms of plant-growth promoting microbes in their root nodules. For example, co-inoculation of soya bean with Bradyrhizobium japonicum and the plant-growth promoting bacterium Serratia proteamaculans increases the onset of nitrogen fixation, percentage plant nitrogen produced, and plant protein content (Dashti et al., 1998). Similarly, endophytic plant-growth promoting bacteria and nitrogen-fixing Rhizobium species were found to work in synergy to promote nitrogen fixation efficiency in Lens culinaris (Veena \& Poonam, 2011).

Not surprisingly, legumes are often over-represented among invasive plant taxa (Daehler, 1998) with some taxa emerging as model systems within invasion biology, e.g. Australian acacias (Richardson et al., 2011). Many species of acacias have been moved around the world for various purposes, with many records of invasiveness. In particular, in South Africa dense monospecific stands of acacias cover tens of thousands of hectares, with substantial impacts, including changes in the soil microbial structure as a result of increased soil nitrogen (Gaertner et al., 2009; Le Maitre et al., 2011). The success of Acacia invasions globally has been attributed to a number of factors such as repeated introductions, introductions of large seed volumes, and concerted breeding efforts by scientists (Le Roux et al., 2011). However, it is also likely that mutualisms, such as the legume-rhizobial symbioses, play an important role in the establishment and invasion success of acacias (RodríguezEcheverría et al., 2011). Despite the huge introduction efforts and successful invasions by Australian acacias in South Africa, little is known of the diversity and origin of rhizobia nodulating these species and their role in the invasion process (but see Rodríguez-Echeverría et al., 2011). Here, we use Acacia pycnantha Benth., a tree native to eastern and southeastern Australia and invasive in the Eastern and Western Cape Provinces of South Africa, to understand the diversity and role of rhizobial symbionts in its invasion success. Specifically we aimed to: (1) determine the taxonomic diversity 
of rhizobia associated with root nodules of A. pycnantha in both native and invasive ranges; (2) determine whether rhizobial associates of invasive A. pycnantha in South Africa follow the co-introduction, host-jumping hypothesis, or both; and (3) determine the level of promiscuity of A. pycnantharhizobial associations.

\section{MATERIALS AND METHODS}

\section{Root nodule collection}

During 2009 root nodules were collected from A. pycnantha plants from 10 sites from throughout its native range in Australia. We also collected plants from seven sites in South Africa and one site in Western Australian (Table 1), representing its introduced ranges. At each site, five root nodules were sampled from 10 individual plants. Root nodules from a single host plant were treated as one unit and preserved in the same vial containing silica gel. For phylogenetic analyses we sequenced only one bacterial isolate/host plant because most bacteria retrieved represented Bradyrhizobium spp. (see Results) and all bacteria collected from single hosts appeared to be the same species based on morphology and growth rates. We therefore focused our phylogenetic analyses to include more sites over wider geographic regions rather than more nodules/individuals.

\section{Isolation and culturing of rhizobia}

Dried root nodules were washed thoroughly using tap water to remove all soil particles. Nodules were transferred to sterile water and stored in a refrigerator at $4{ }^{\circ} \mathrm{C}$ overnight to rehydrate (Burdon et al., 1999). Rehydrated nodules were surface-sterilized in $70 \%$ ethanol for $30 \mathrm{~s}$ followed by $3.5 \%$ sodium hypochlorite solution for $5 \mathrm{~min}$. Sterilized nodules were washed at least five separate times in sterile distilled water. The surface sterilized root nodules were then crushed in $300 \mu \mathrm{L}$ sterile distilled water using a sterilized toothpick. $50 \mu \mathrm{L}$ of the turbid suspension was diluted and streaked on yeast manitol agar (YMA) medium (Vincent, 1970) containing Congo Red. Plates were incubated at $28{ }^{\circ} \mathrm{C}$ and examined for bacterial growth after 3-10 days. Well-separated single colonies were restreaked on to fresh plates until pure cultures were obtained. Colony purity was ascertained using Gram staining and light microscopy.

\section{Genomic DNA isolation}

Genomic DNA was extracted by heating bacterial cells in a lysis buffer $(1 \times$ TE: TrisHCl and EDTA $)$ for $5 \mathrm{~min}$ at $95{ }^{\circ} \mathrm{C}$ followed by centrifuging cell lysates for $2 \mathrm{~min}$. The DNA-containing supernatant was collected and washed with chloroform (Parker et al., 2007). All DNA concentrations were quantified by spectroflourimetry and high quality extractions stored at $-20{ }^{\circ} \mathrm{C}$ until further use.

\section{DNA fingerprinting}

To obtain an overall idea of bacterial diversity among isolates a preliminary repetitive element polymerase chain reaction (REP-PCR) fingerprinting was performed using a fluorescently labelled enterobacterial repetitive intergenic consensus primer (ERIC1) (5'-ATG TAA GCT CCT GGG GAT TCA-3') and a BOX primer (5'-CTA CGG CAA GGC GAC GCT GAC G-3') (Versalovic et al., 1994). The REP-PCR was carried out in $20 \mu \mathrm{L}$ reactions containing 5 pmol of each primer, $25 \mathrm{ng}$ template bacterial DNA, $0.4 \mu \mathrm{L}$ of $10 \mathrm{~mm}$ dNTPs, $5 \mathrm{U}$ taq (Kapa Biosystems, Boston, MA, USA), $10 \mathrm{mg} \mathrm{mL}^{-1}$ bovine serum albumen (BSA) and $4 \mu \mathrm{L}$ of $5 \times$ buffer. PCR amplifications were performed in an automated thermocycler with initial denaturation of $95{ }^{\circ} \mathrm{C}$ for $2 \mathrm{~min}$, followed by 40 cycles of denaturation $\left(94^{\circ} \mathrm{C}\right.$ for $60 \mathrm{~s}$, $53{ }^{\circ} \mathrm{C}$ for $60 \mathrm{~s}, 65^{\circ} \mathrm{C}$ for $8 \mathrm{~min}$ ) and a final extension temperature of $65{ }^{\circ} \mathrm{C}$ for $8 \mathrm{~min}$. PCR products were separated on $2 \%$ agarose gels to confirm successful amplification prior to genotyping (Versalovic et al., 1994). PCR fragments were separated on an ABI Prism 3100 Genetic Analyzer (Applied Biosystems, Foster City, CA, USA), using GeneScan ${ }^{\mathrm{TM}}-500$ $(-250)$ as an internal size standard (Applied Biosystems). Allele sizes were visualized and scored as presence or absence of amplicons using GENEMARKER ${ }^{\circledR} 1.95$ (SoftGenetics LLC ${ }^{\circledR}$, State College, PA, USA). A binary matrix of presence and absence data was generated for all amplified fragments. These data were used to reconstruct a dendrogram using a neighbour-joining distance algorithm as implemented in PAUP $^{*} 4$ (Swofford, 2002).

\section{PCR conditions and DNA sequencing}

Distinct clusters from the ERIC and BOX fingerprinting tree were visually identified. At least two representative isolates were chosen from each cluster and sequenced using the 16S-23S rRNA intergenic spacer region (IGS). IGS amplification was carried out using the primers FGPS 1490-72 (5'-TGC GGC TGG ATC CCC TCC TT-3') and FGPL 132'-38 (5'-CCG GGT TTC CCC ATT CGG-3') (Romdhane et al., 2005). Each $50 \mu \mathrm{L}$ reaction contained 5 pmol of each primer, $0.5 \mu \mathrm{L}$ of $20 \mathrm{~mm}$ dNTPs, $10 \times$ buffer, $1.5 \mathrm{~mm}$ magnesium chloride and $0.5 \mu \mathrm{L}$ Super-Therm polymerase JMR-801

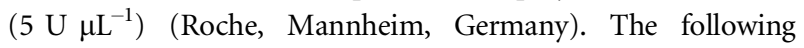
PCR cycle was used: $94{ }^{\circ} \mathrm{C}$ for 5 min denaturation followed by 30 cycles of $\left(94{ }^{\circ} \mathrm{C}\right.$ for $30 \mathrm{~s}, 58^{\circ} \mathrm{C}$ for $30 \mathrm{~s}$ annealing and $72{ }^{\circ} \mathrm{C}$ for $60 \mathrm{~s}$ ) followed by a final extension step at $72{ }^{\circ} \mathrm{C}$ for $7 \mathrm{~min}$ and a final holding temperature of $15^{\circ} \mathrm{C}$. A preliminary BLAST search of the 16S-23S IGS sequences was performed to compare sequences obtained against the NCBI database. Sequences that had a similarity index below $96 \%$ could not be used to reliably identify isolates to species level were reamplified with the $16 \mathrm{~S}$ rRNA primers, 16SA (5'-AGA GTT TGA TCC TGG CTC AG-3') and 16SB (5'-AAG GAG GTC ATC CAG CC-3') (Weisburg et al., 1991). For the latter, PCR reactions were carried out in $50 \mu \mathrm{L}$ reactions containing 
Table 1 Rhizobial strains used in the phylogenetic analyses of root nodule and rhizospheric microbial symbionts associated with Acacia pycnantha in its native (Australian) and invasive (South African and Western Australian) ranges.

\begin{tabular}{|c|c|c|c|c|c|c|c|}
\hline \multirow[b]{2}{*}{ Sample ID } & \multirow[b]{2}{*}{ Country } & \multirow[b]{2}{*}{ Locality } & \multirow[b]{2}{*}{ Latitude } & \multirow[b]{2}{*}{ Longitude } & \multicolumn{3}{|c|}{ GenBank accession numbers } \\
\hline & & & & & 16S-23S IGS & 16S rRNA & $\operatorname{nodA}$ \\
\hline JNR1 & SA & Caledon & -33.10701 & 19.29755 & NA & KC207926 & NA \\
\hline JNR2 & SA & Caledon & -33.10701 & 19.29755 & HQ895988 & NA & NA \\
\hline JNR5 & SA & Caledon & -33.10701 & 19.29755 & HQ895989 & NA & NA \\
\hline JNR6 & SA & Caledon & -33.10701 & 19.29755 & HQ895990 & $\mathrm{NA}$ & KC297661 \\
\hline JNR8 & SA & Caledon & -33.10701 & 19.29755 & HQ895991 & NA & NA \\
\hline JNR20 & SA & Humansdorp & -34.03989 & 24.78687 & NA & KC207924 & NA \\
\hline JNR22 & SA & Humansdorp & -34.03989 & 24.78687 & NA & KC207922 & NA \\
\hline JNR24 & SA & Humansdorp & -34.03989 & 24.78687 & NA & KC207913 & NA \\
\hline JNR25 & SA & Humansdorp & -34.03989 & 24.78687 & NA & KC207925 & NA \\
\hline JNR26 & SA & Humansdorp & -34.03989 & 24.78687 & NA & KC207920 & NA \\
\hline JNR27 & SA & Humansdorp & -34.03989 & 24.78687 & NA & KC207923 & NA \\
\hline JNR28 & SA & Humansdorp & -34.03989 & 24.78687 & NA & KC207911 & NA \\
\hline JNR30 & SA & Humansdorp & -34.03989 & 24.78687 & HQ895993 & NA & KC297663 \\
\hline JNR31 & SA & Wolseley & -33.34012 & 19.16109 & HQ895994 & NA & KC297664 \\
\hline JNR32 & SA & Wolseley & -33.34012 & 19.16109 & KC207904 & NA & KC297665 \\
\hline JNR35 & SA & Wolsely & -33.34012 & 19.16109 & HQ895995 & NA & KC297666 \\
\hline JNR37 & SA & Wolsely & -33.34012 & 19.16109 & HQ895996 & NA & KC297667 \\
\hline JNR42 & SA & Tokai & -33.84179 & 18.66602 & NA & KC207921 & NA \\
\hline JNR44 & SA & Tokai & -33.84179 & 18.66602 & HQ895997 & NA & KC297668 \\
\hline JNR53 & SA & Stellenbosch & -34.06024 & 18.41480 & KC207906 & NA & KC297669 \\
\hline JNR54 & SA & Stellenbosch & -34.06024 & 18.41480 & HQ895998 & NA & KC297662 \\
\hline JNR56 & SA & Stellenbosch & -34.06024 & 18.41480 & NA & KC207917 & NA \\
\hline JNR57 & SA & Stellenbosch & -34.06024 & 18.41480 & KC207905 & NA & KC297670 \\
\hline JNR138 & SA & Piketberg & -32.80084 & 18.71501 & HQ896012 & NA & NA \\
\hline JNR62 & AUS & Esperance & -34.31586 & 118.79919 & NA & NA & KC297671 \\
\hline JNR63 & AUS & Esperance & -34.31586 & 118.79919 & KC207903 & NA & NA \\
\hline JNR65 & AUS & Esperance & -34.31586 & 118.79919 & NA & KC207930 & NA \\
\hline JNR67 & AUS & Esperance & -34.31586 & 118.79919 & NA & KC207933 & NA \\
\hline JNR69 & AUS & Esperance & -34.31586 & 118.79919 & HQ896000 & NA & NA \\
\hline JNR71 & AUS & Esperance & -34.31586 & 118.79919 & KC297672 & NA & KC297672 \\
\hline JNR78 & AUS & Melrose & -32.78187 & 138.1973 & KC207902 & NA & NA \\
\hline JNR80 & AUS & Melrose & -32.78187 & 138.1973 & HQ896003 & NA & KC297674 \\
\hline JNR83 & AUS & Melrose & -32.78187 & 138.1973 & HQ896004 & NA & KC297675 \\
\hline JNR85 & AUS & Melrose & -32.78187 & 138.1973 & KC207899 & NA & KC297676 \\
\hline JNR86 & AUS & Frances & -36.77054 & 141.18135 & NA & KC207912 & NA \\
\hline JNR89 & AUS & Frances & -36.77054 & 141.18135 & HQ896005 & NA & KC297680 \\
\hline JNR93 & AUS & New South Wales & -35.99273 & 143.76538 & KC207900 & NA & KC297677 \\
\hline JNR94 & AUS & New South Wales & -35.99273 & 143.76538 & NA & KC207932 & NA \\
\hline JNR98 & AUS & Mt Jerrabomberra & -35.36866 & 149.20332 & NA & NA & KC297678 \\
\hline JNR100 & AUS & Mt Jerrabomberra & -35.36866 & 149.20332 & NA & KC207910 & NA \\
\hline JNR101 & AUS & Mt Jerrabomberra & -35.36866 & 149.20332 & KC207901 & NA & KC297679 \\
\hline JNR104 & AUS & Natimuk & -36.00409 & 143.76041 & NA & KC207916 & NA \\
\hline JNR109 & AUS & Natimuk & -36.00409 & 143.76041 & NA & KC207919 & NA \\
\hline JNR112 & AUS & Natimuk & -36.00409 & 143.76041 & NA & KC207931 & NA \\
\hline JNR117 & AUS & Mt Compass & -35.40585 & 145.95586 & NA & KC207914 & NA \\
\hline JNR118 & AUS & Mt Compass & -35.40585 & 145.95586 & NA & KC207928 & NA \\
\hline JNR120 & AUS & Wagawaga & -35.21065 & 147.76425 & NA & KC207918 & NA \\
\hline JNR125 & AUS & Wagawaga & -35.21065 & 147.76425 & NA & KC207909 & NA \\
\hline JNR126 & AUS & Wagawaga & -35.21065 & 147.76425 & NA & KC207908 & NA \\
\hline JNR129 & AUS & Lockhart & -35.36866 & 146.64549 & NA & KC207907 & NA \\
\hline JNR131 & AUS & Lockhart & -35.36866 & 146.64549 & NA & KC207915 & NA \\
\hline JNR132 & AUS & Lockhart & -35.36866 & 146.64549 & NA & KC207927 & NA \\
\hline JNR135 & AUS & Lockhart & -35.36866 & 146.64549 & NA & КС207929 & NA \\
\hline
\end{tabular}

AUS, Australia; SA, South Africa; IGS, intergenic spacer; NA, not applicable. 
5 pmol of the forward and reverse primers, $1 \mu \mathrm{L}$ of $20 \mathrm{~mm}$ dNTP mix, $5 \mu \mathrm{L}$ of $10 \times$ buffer, $1.5 \mathrm{~mm}$ magnesium chloride, $1 \mu \mathrm{L}$ BSA and $24.5 \mu \mathrm{L}$ water. The following cycle was used: an initial denaturation of $95{ }^{\circ} \mathrm{C}$ for 2 min followed by 30 cycles of $\left(95{ }^{\circ} \mathrm{C}\right.$ for $30 \mathrm{~s}, 54{ }^{\circ} \mathrm{C}$ for $30 \mathrm{~s}$ annealing and $72{ }^{\circ} \mathrm{C}$ for $4 \mathrm{~min}$ ) followed by a final extension step of $72{ }^{\circ} \mathrm{C}$ for $20 \mathrm{~min}$ and a holding temperature of $15^{\circ} \mathrm{C}$.

The nodA gene, which is commonly used as a biogeographic marker in rhizobial phylogenetics (Rodríguez-Echeverría, 2010), was amplified for isolates that were identified as Bradyrhizobium spp. using the primers TSnodD1-1C (5'- CAG ATC NAG DCC BTT GAA RCG CA-3') and TSnodB1 (5'- AGG ATA YCC GTC GTG CAG GAG CA-3') /TSnodA2 (5'-GCT GAT TCC AAG BCC YTC VAG ATC-3') (Moulin et al., 2004). The following cycle was used: $94{ }^{\circ} \mathrm{C}$ for $2 \mathrm{~min}$, followed by 30 cycles of $\left(95^{\circ} \mathrm{C}\right.$ for $30 \mathrm{~s}, 56^{\circ} \mathrm{C} /$ $55{ }^{\circ} \mathrm{C}$ for $30 \mathrm{~s}, 72{ }^{\circ} \mathrm{C}$ for $45 \mathrm{~s}$ ) and a final extension temperature of $72{ }^{\circ} \mathrm{C}$ for $7 \mathrm{~min}$ (Rodríguez-Echeverría, 2010). The nodA gene (350 bp fragment) was sequenced for all isolates included in the 16S rRNA analysis and also to check whether taxa identified as Burkholderia (see Results) were actually nodulating bacteria. Burkholderia terricola was used as a positive control for the latter. For Burkholderia accessions, the nodA gene was amplified using the primers nodA A (5'-TGG ARV BTN YSY TGG GAA A-3') and nodB B (5'-CCR AAV SCR AAY GGV AC-3') and the following thermocycle: $94{ }^{\circ} \mathrm{C}$ for 2 min followed by 35 cycles of $\left(94{ }^{\circ} \mathrm{C}\right.$ for $45 \mathrm{~s}, 55^{\circ} \mathrm{C}$ for $30 \mathrm{~s}, 72{ }^{\circ} \mathrm{C}$ for $45 \mathrm{~s}$ ) and a final extension temperature of $72{ }^{\circ} \mathrm{C}$ for $7 \mathrm{~min}$ (Chen et al., 2005).

\section{Molecular characterization of isolates and phylogenetic analysis}

A BLAST search of the 16S-23S IGS, 16S rRNA and the $\operatorname{nodA}$ gene sequences was performed to compare sequences obtained in this study against existing data available in GenBank (http://blast.ncbi.nlm.nih.gov). Australian and South African sequences available from GenBank that revealed high similarities to those obtained here (96-100\% similarity) were also included in the reconstruction of phylogenies. Datasets for all gene regions were aligned using CLustal W (Thompson et al., 1994) and manually edited in BioEdit 7.0.5.3 (Hall, 1999). All three gene phylogenies were reconstructed using maximum parsimony as implemented in PAUP $^{\star} 4$ with the heuristic search options (Swofford, 2002) and Bayesian inference in MrBayes 3.1.2 (Ronquist \& Huelsenbeck, 2003). MrBAyes was run for two million generations and trees sampled every 100 generations for all the three genes. Confidence in tree topologies for maximum parsimony was determined using 1000 bootstrap replicates while Bayesian posterior probabilities were determined with the Bayesian Markov chain Monte Carlo method implemented in MrBAYES 3.1.2. Prior to analyses, the best fit model for evolution for each of the datasets was determined using the Akaike information criterion (AIC) as implemented in Modeltest 3.7 (Posoda \& Crandall, 1998). The model of evolution used to reconstruct the Bradyrhizobium phylogeny was the HKY + $\mathrm{I}+\mathrm{G}$ model, while the $\operatorname{TrN}+\mathrm{I}+\mathrm{G}$ and the TVM $+\mathrm{G}$ models were used for the $16 \mathrm{~S}$ rRNA and nodA phylogenies, respectively. Because the latter two models are not implemented in MrBayes, we used the GTR + G model.

\section{RESULTS}

From 180 collected root nodules, 125 produced colonies resembling rhizobia. Among these there was a mixture of fast-growing and slow-growing bacteria. Most colonies from native range regions were fast growing (c. 63\%) while most colonies from invasive ranges were slow growing (c. 80\%).

Neighbour joining analysis of the REP-PCR and ERICPCR fingerprints revealed 12 distinct genetic clusters of bacterial symbionts (results not shown). Overall, Australian (native) and South African (invasive) isolates were found in most clusters retrieved, with the exception of one cluster that contained only Australian isolates.

\section{S-23S rRNA - Bradyrhizobium}

All sequences of slow-growing bacteria showed high similarity $(>96 \%)$ to accessions of B. japonicum lodged in GenBank. All the trees obtained from the two different analyses (Bayesian and maximum parsimony) retrieved similar topologies so only the Bayesian tree is shown here (Fig. 1). All analyses separated the Bradyrhizobium isolates into nine wellsupported and distinct clades (Fig. 1). Clade 6 consisted of isolates with Australian origins, while clade 2 and clade 9 consisted of accessions collected from A. pycnantha from both native and invasive ranges. Clade 1 and Clade 5 consisted of isolates that were unique to the invasive range in South Africa. Most of the Portuguese isolates that had an Australian origin (based on the nodA and nifD genes, see Rodríguez-Echeverría, 2010) were found in cluster seven.

\section{$\operatorname{nod} A$}

Partial nodA DNA sequences obtained in this study, and additional data for Bradyrhizobium spp. isolated from root nodules of different species in Australia and southern Africa (Botswana, South Africa and Zimbabwe) obtained from GenBank, were used for phylogenetic reconstruction. Two geographically distinct clades were resolved in the analysis (Fig. 2). Clade 1 consisted of exclusively southern African accessions (isolated from root nodules of Arachis hypogaea and Vigna unguiculata), while Clade 2 included mostly Australian accessions and isolates from South Africa (invasive A. pycnantha and A. decurrens). All invasive A. pycnantha isolates from South Africa grouped within the Australian clade.

\section{S rRNA}

All of the fast-growing bacteria sequenced using the 16S-23S rRNA IGS region showed low overall similarity $(<96 \%)$ to 


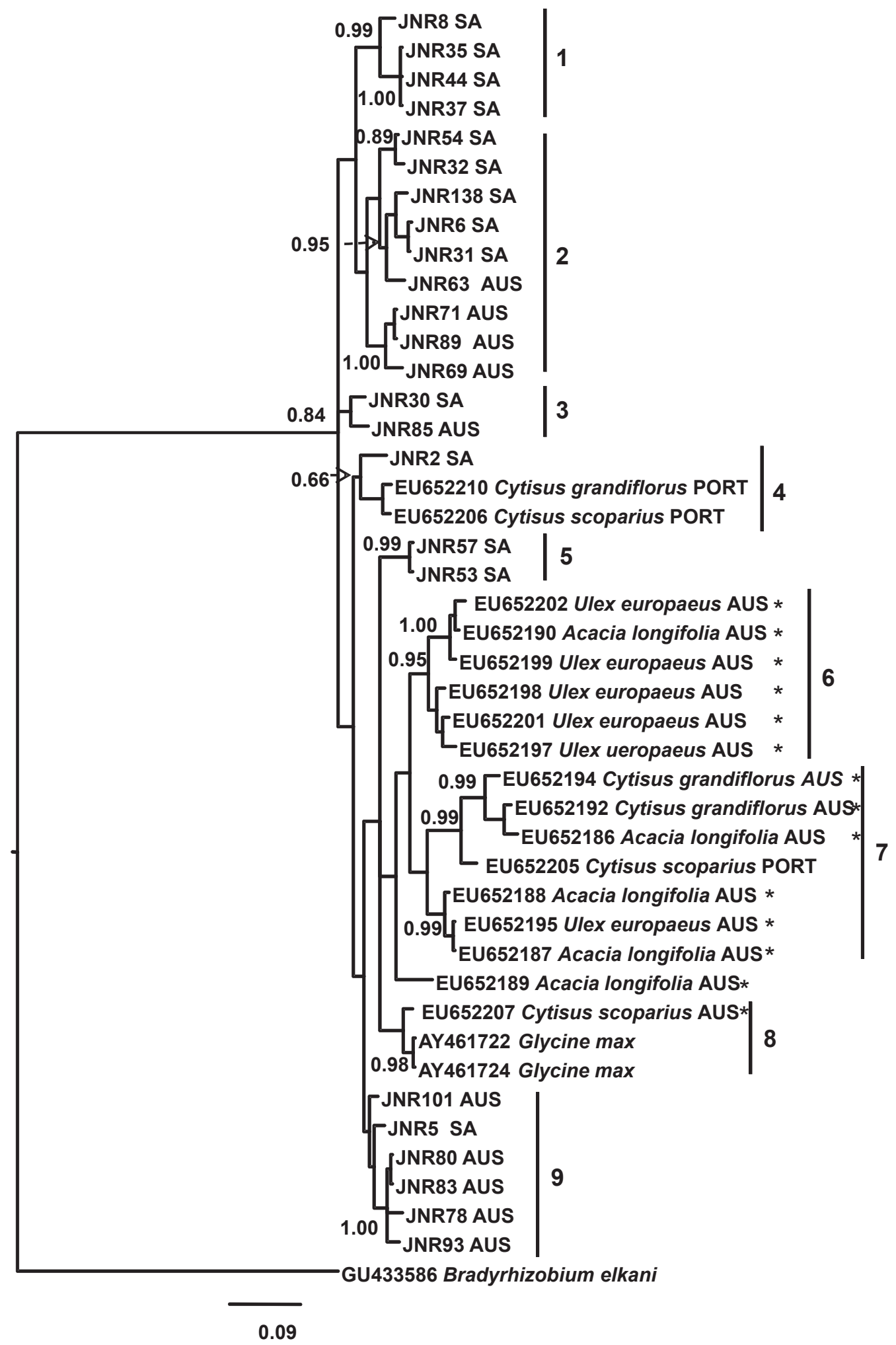

Figure 1 Bayesian tree of Bradyrhizobium japonicum symbionts associated with Acacia pycnantha based on the 16S-23S rRNA intergenic spacer (IGS) gene. The tree also includes reference bacterial strains isolated from various legume species, as indicated. Nodal support is given as posterior probability values. The scale bar represents the number of substitutions per site. Geographical origins are abbreviated: AUS, Australia; PORT, Portugal; SA, South Africa. Please note that, despite being collected in Portugal, accessions labelled with asterisks are thought to be of Australian origin based on a previous phylogeographic study (Rodríguez-Echeverría, 2010). 


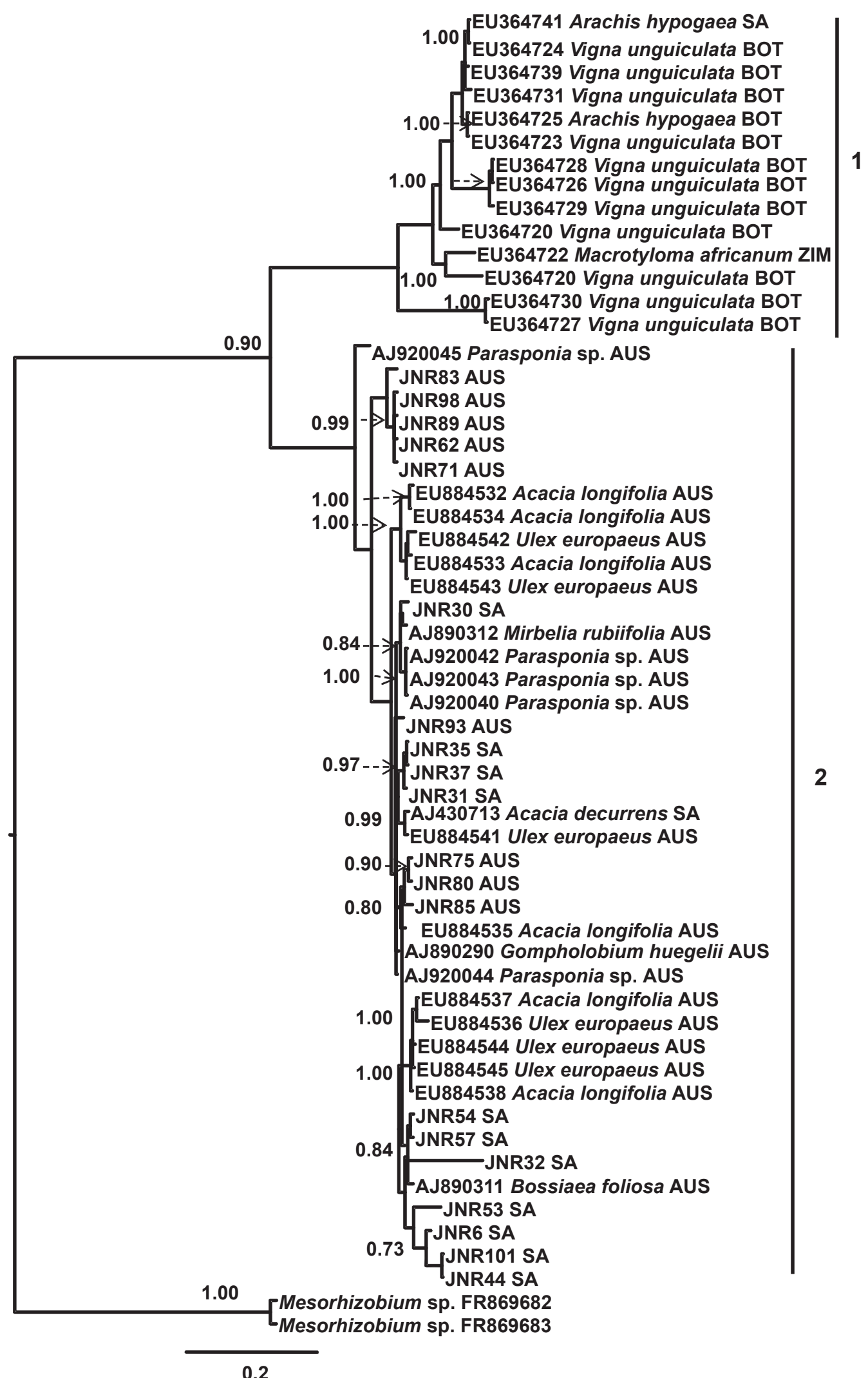

Figure 2 Bayesian tree based on the nodA gene of Bradyrhizobium japonicum symbionts associated with Acacia pycnantha. The tree also includes reference bacterial strains isolated from various legume species, as indicated. Posterior probability values $>80 \%$ are indicated. The scale bar represents the number of substitutions per site. Geographical origins are abbreviated: AUS, Australia; BOT, Botswana; SA, South Africa; ZIM, Zimbabwe. 
any accessions deposited in GenBank. Re-sequencing these fast-growing isolates with the $16 \mathrm{~S}$ rRNA primers yielded sequences with a high similarity index to sequences contained in GenBank and identified fast-growing bacteria as similar to Burkholderia, Rhizobium and Mesorhizobium species. The 16S rRNA phylogeny retrieved two major clades with one belonging to the alpha proteobacteria (Mesorhizobium and Rhizobium) and the other belonging to the beta proteobacteria (Burkholderia) (Fig. 3). In South Africa, isolates resembling Mesorhizobium spp., Rhizobium miluonense, $R$. multihospitium and $R$. tropici were retrieved, while in Australia $R$. gallicum and $R$. lusitanum were most closely related to fast-growing bacteria isolated from A. pycnantha. In addition, rhizobia closely related to $R$. cellulolyticum and $R$. yanglingense (which are known to form ineffective nodules in Phaselous vulgaris; Tan et al., 2001; García-Fraile et al., 2007) were found in the root nodules of $A$. pycnantha from Australia. The $16 \mathrm{~S}$ rRNA phylogenetic tree placed the Burkholderia sequences from Australia and South Africa into a single well-supported clade that included Burkholderia caledonica, B. graminis and B. phytofirmans (Fig. 3). Both South African and Australian bacteria included B. phytofirmans and B. caledonica, while a strain similar to B. graminis (JNR104) was found in Australia only. All three species identified here are not known to nodulate legumes or fix nitrogen and therefore amplification of the nodA gene (which facilitates nodulation) failed for all the isolates. To confirm this, we successfully amplified $\operatorname{nodA}$ in $B$. terricola, a known nodulating symbiont of Virgilia oroboides in South Africa (A. Magadlela, Stellenbosch University, pers. comm.), using the same PCR conditions and primers.

\section{DISCUSSION}

Acacia pycnantha in its invasive range in South Africa was co-introduced with at least some of its native symbionts from Australia (co-introduction hypothesis). Acacia pycnantha is also a highly promiscuous nitrogen fixer capable of forming mutualistic associations with a wide range of symbionts in its introduced range. It forms associations with members of the genus Burkholderia, although these associations probably do not result in the fixation of atmospheric nitrogen. Such promiscuity is not surprising because other closely related species such as Acacia cyclops, A. saligna, A. melanoxylon and Paraserianthes lophantha also form new rhizobial associations when cultivated in soils from their non-native ranges (Birnbaum et al., 2012). Acacia therefore appears to consist of generalist species, which do not require specific rhizobial species to fix nitrogen outside their native range (Rodríguez-Echeverría et al., 2011; Birnbaum et al., 2012).

Given the pivotal role of mutualisms in invasion success (Richardson et al., 2000), species with highly specialized obligate mutualistic associations are often under-represented in invasive floras, e.g. members of the Orchidaceae (Daehler, 1998). The ability of Australian acacias to nodulate and fix nitrogen must have been a substantial factor contributing to their success in South Africa's fynbos biome, which is characterized by soils that are generally poor in nutrients, especially nitrogen (Slabbert et al., 2010). While it is an advantage to form these mutualisms, the ability to form mutualistic partners with a wider range of rhizobial symbionts (generalist legumes) must confer advantages to introduced legumes in their new environments. Invasive $A$. pycnantha in South Africa is a generalist species associated with a range of different and distantly related rhizobia, including Bradyrhizobium japonicum, Rhizobium gallicum, $R$. miluonense, $R$. multihospitium and $R$. tropici. To the best of our knowledge this is the first record of both $R$. miluonense and R. multihospitium associated with an Australian Acacia. Rhizobium multihospitium was isolated from several legumes in China (Han et al., 2008). Similarly, R. miluonense was isolated from the root nodules of Lespedeza species in China (Gu et al., 2008). Highly promiscuous legumes do not require co-introduction with compatible rhizobia from their native regions and may easily recruit novel microsymbionts in their new environments (Rodríguez-Echeverría et al., 2011).

Our phylogenetic results indicate that B. japonicum symbionts were most likely co-introduced with A. pycnantha from Australia (Figs 1 \& 2). Without knowledge of native legumerhizobia associations, novel mutualisms between A. pycnantha and South African rhizobia remain speculative. However, the association between A. pycnantha and bacteria known only from Asia ( $R$. miluonense and R. multihospitium) supports the host-jumping hypothesis. While the phylogeographic utility of the 16S-23S rRNA IGS gene region (Fig. 1) has been questioned (Rodríguez-Echeverría, 2010), the co-introduction of symbionts from Australia is further supported by our nodulation gene (nodA) phylogeny. Nodulation genes have been widely used and have proven to be reliable phylogeographic markers for rhizobial lineages (Weir et al., 2004). Our results confirmed that A. pycnantha brought most, if not all, of its Bradyrhizobium symbionts along from Australia (Fig. 3). All the A. pycnantha isolates from South Africa grouped within the Australian clade (Clade 2; Fig. 2). Overall, invasive A. pycnantha in South Africa appears to conform to both the co-introduction and the host-jumping hypothesis. Consequently, A. pycnantha utilizes a wider suite of symbionts in its invasive range than its native range. This finding contrasts with previous work that showed Australian acacias to generally utilize a wider variety of mutualists in their native than invasive ranges (e.g. Weir et al., 2004; Rodríguez-Echeverría, 2010; RodríguezEcheverría et al., 2011).

In addition to the conventional rhizobial taxa found associated with A. pycnantha in Australia and South Africa, we also identified various Burkholderia taxa. The association of some beta-proteobacterial genera capable of fixing atmospheric nitrogen, including Burkholderia, has been known for some time (Moulin et al., 2001). In particular, we isolated and identified B. caledonica, B. graminis and B. phytofirmans from root nodules of $A$. pycnantha. While nitrogen-fixing 


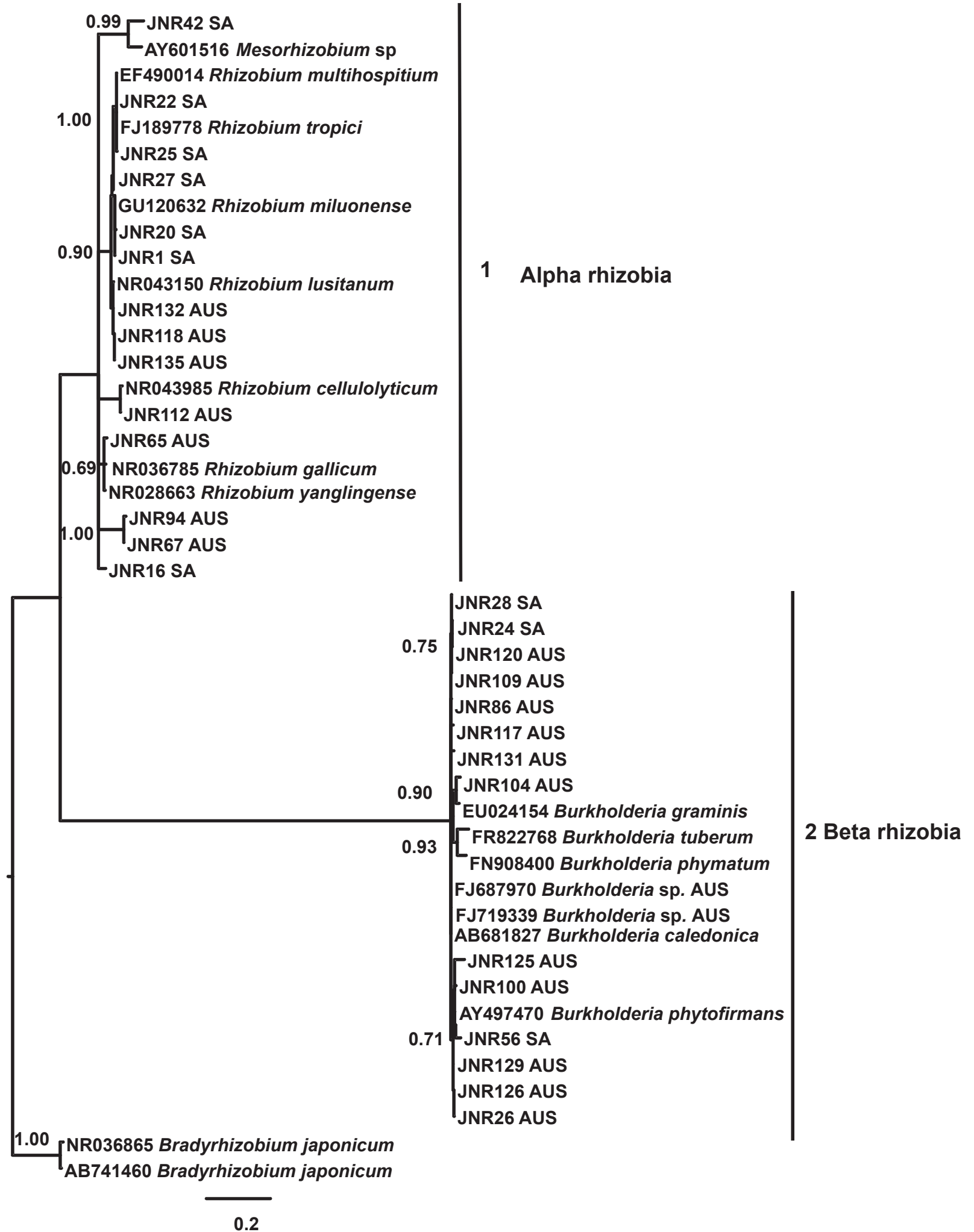

Figure 3 Bayesian tree based on the 16S rRNA gene for Burkholderia, Rhizobium and Mesorhizobium symbionts found associated with Acacia pycnantha in South Africa and Australia. GenBank accession numbers are given for reference taxa included from GenBank. Nodal support is given as Bayesian posterior probability values. The scale bar represents the number of substitutions per site. Geographical origins of A. pycnantha symbionts are abbreviated: AUS, Australia; SA, South Africa. 
Burkholderia endosymbionts have been previously described from numerous South African legumes (Elliot et al., 2007), and it is hypothesized that the group has a primarily Neotropical origin (Bontemps et al., 2010). As far as we know, no indigenous nodulating Burkholderia strains are known from Australia. Numerous attempts to amplify nodulation genes $(\operatorname{nod} A)$ in these isolates failed, whereas we could successfully amplify nodulations genes from $B$. terricola, which nodulates South African legumes and fixes nitrogen (A. Magadlela, pers. comm.). Nevertheless, the frequency of Burkholderia strains was overall very high, and therefore not considered to be the result of contamination but is likely to reflect true symbionts. Whilst these taxa appear incapable of fixing nitrogen, the data raise the fundamental question of whether these bacteria have benefits to their hosts. Two of these species, B. caledonica and B. graminis, have been previously recorded as common rhizosphere inhabitants (Compant et al., 2008), while others have been found to be specifically associated with the rhizospheres of Australian acacias (Hoque et al., 2011). These rhizosphere bacteria can form beneficial associations with their hosts, although the nature of these associations remains uncertain. Plant-growth promoting rhizobacteria can colonize the plant anterior and thrive as endophytes in various plant organs without causing harm to their hosts (Compant et al., 2008). These bacteria initially colonize the root surface followed by the subsequent entrance into the endorhiza mainly through the root tip, lateral root cracks or rhizodermal cells via cell wall degrading enzyme secretions (Compant et al., 2008). Plant growth promoters can directly exert positive effects to plants through the synthesis of phytohormones and solubilization of inorganic phosphates and mineralization of organic phosphates (Rodríguez \& Fraga, 1999).

The isolation of B. phytofirmans from root nodules of $A$. pycnantha from both native and invasive ranges is a significant finding. Burkholderia phytofirmans has been largely recognized as a plant-growth promoting bacterium. For example, associations with B. phytofirmans enlarge root systems with enhanced secondary roots and more root hairs and thus the opportunity to form root nodules by rhizobia. Association with $B$. phytofirmans also frequently leads to the development of more and larger leaf hairs, steadier stems, higher lignin deposits around the vascular system, larger amounts of chlorophyll, increased levels of cytokinins and phenylalanine ammonia, and pathogen resistance (Compant et al., 2008). Assuming that the endophytic bacteria confer some or all of these advantages to legumes that already have the ability to overcome the negative effects caused by nitrogen stress, plant establishment and subsequent invasions will therefore benefit. However, more research is needed to understand the role of the endophytic bacteria not only in the establishment success of the genus Acacia, but for introduced legumes in general. This information will not only advance our understanding of the invasion dynamics of Australian acacias but may also increase the value of these species for agroforestry. To date, Burkholderia has been isolated from root nodules or the rhizosphere of A. pycnantha, A. salicina, A. stenophylla and A. decurrens (Menna et al., 2006; Hoque et al., 2011; Rodríguez-Echeverría et al., 2011). We recommend that future research should focus on assessing the beneficial properties that these endophytic Burkholderia species may render invasive legumes.

Finally, in the South African fynbos, where A. pycnantha is invasive, indigenous legumes show distinct, and some even peculiar, rhizobial associations. For example, the genus $\mathrm{Cycl}$ opia is nodulated primarily by Burkholderia species, while some Lotononis species are nodulated by Methylobacterium nodulans (Sy et al., 2001; Ardley et al., 2009); both groups are very distantly related to conventional rhizobia. The diversity of rhizobial symbionts in the fynbos offers an exciting opportunity to study how the interactions between indigenous and introduced bacteria affect both native and introduced legume species, a largely unexplored topic. A comprehensive study of symbiotic genes will allow for a detailed framework on how lateral gene transfer (if and when it occurs) between different species of bacteria allows for new genetic combinations that can form novel genotypes, which may enhance invasiveness.

\section{ACKNOWLEDGEMENTS}

This work was funded primarily by DST-NRF Centre of Excellence for Invasion Biology $(\mathrm{C} \cdot \mathrm{I} \cdot \mathrm{B})$ and the Working for Water Programme through their collaborative research project on 'Research for Integrated Management of Invasive Alien Species'. Additional funding was supplied by grants to D.M.R. from the National Research Foundation and the Hans Sigrist Foundation. J.J.LeR. also acknowledges the National Research Foundation for funding. The authors thank Pauline Ladiges and two anonymous referees for helpful comments on previous drafts of the manuscript.

\section{REFERENCES}

Ardley, J.K., O’Hara, G.W., Reeve, W.G., Yates, R.J., Dilworth, M.J., Tiwari, R.P. \& Howieson, J.G. (2009) Root nodule bacteria isolated from South African Lotononis bainesii, L. listii and L. solitudinis species of Methylobacterium that are unable to utilize methanol. Archives of Microbiology, 191, 311-318.

Birnbaum, C., Barret, L., Thrall, P.H. \& Leishman, M.R. (2012) Mutualisms are not constraining cross-continental invasional success of Acacia species within Australia. Diversity and Distributions, 18, 962-976.

Bontemps, C., Elliott, G.N., Simon, M.F., dos Reis Junior, F.B., Gross, E., Lawton, R.C., Neto, N.E., Loureiro, M.F., de Faria, S.M., Sprent, J.I., James, E.K. \& Young, J.P. (2010) Burkholderia species are ancient symbionts of legumes. Molecular Ecology, 19, 44-52.

Burdon, J.J., Gibson, H., Searle, S.D., Woods, M.J. \& Brockwell, J. (1999) Variation in the effectiveness of symbiotic associations between native rhizobia and temperate 
Australian Acacia: within-species interactions. Journal of Applied Ecology, 36, 398-408.

Chen, W.M., James, E.K., Chou, J.H., Sheu, S.Y., Yang, S.Z. \& Sprent, J.I. (2005) Beta-rhizobia from Mimosa pigra, a newly discovered invasive plant in Taiwan. New Phytologist, 168, 661-675.

Compant, S., Nowak, J., Coenye, T., Clément, C. \& Barka, E.A. (2008) Diversity and occurrence of Burkholderia spp. in the natural environment. FEMS Microbiology Reviews, 32, 607-626.

Crisóstomo, J.A., Rodríguez-Echeverría, S. \& Freitas, H. (2013) Co-introduction of exotic rhizobia to the rhizosphere of the invasive legume Acacia saligna, an intercontinental study. Applied Soil Ecology, 64, 118-126.

Daehler, C.C. (1998) The taxonomic distribution of invasive angiosperm plants: ecological insights and comparison to agricultural weeds. Biological Conservation, 84, 167-180.

Dashti, N., Zhang, F., Hynes, R. \& Smith, D.L. (1998) Plant growth promoting rhizobacteria accelerate nodulation and increase nitrogen fixation activity by field grown soybean [Glycine max (L.) Merr.] under short season conditions. Plant and Soil, 200, 205-213.

Elliot, G.N., Chen, W.M., Bontemps, C., Chou, J.H., Young, J.P.W., Sprent, J.I. \& James, E.K. (2007) Nodulation of Cyclopia spp. (Leguminosae, Papilionoideae) by Burkholderia tuberum. Annals of Botany, 100, 1403-1411.

Gaertner, M., Den Breeÿen, A., Hui, C. \& Richardson, D.M. (2009) Impacts of alien plant invasions on species richness in Mediterranean-type ecosystems: a meta-analysis. Progress in Physical Geography, 33, 319-338.

García-Fraile, P., Rivaz, R., Willems, A., Peix, A., Martens, M., Martínez-Molina, E., Mateos, P.F. \& Veláquez, E. (2007) Rhizobium cellulosilyticum sp. nov., isolated from sawdust of Populus alba. International Journal of Systematic and Evolutionary Microbiology, 57, 844-848.

Gu, C.T., Wang, E.T., Tian, C.F., Han, T.X., Chen, W.F., Sui, X.H. \& Chen, W.X. (2008) Rhizobium miluonense sp. nov., a symbiotic bacterium isolated from Laspedeza root nodules. International Journal of Systematic and Evolutionary Microbiology, 58, 1364-1368.

Hall, T.A. (1999) BioEdit: a user-friendly biological sequence alignment editor and analysis program for Windows 95/ 98/NT. Nucleic Acids Symposium Series, 41, 95-98.

Han, T.X., Wand, E.T., Wu, L.J., Chen, W.F., Gu, J.G., Gu, C.T., Tian, C.F. \& Chen, W.X. (2008) Rhizobium multihospitum sp. nov., isolated from multiple legume species native of Xinjian, China. International Journal of Systematic and Evolutionary Microbiology, 58, 1693-1699.

Hoque, M.S., Broadhurst, L.M. \& Thrall, P.H. (2011) Genetic characterization of root-nodule bacteria associated with Acacia salicina and A. stenophylla (Mimosaceae) across south-eastern Australia. International Journal of Systematic and Evolutionary Microbiology, 61, 299-309.

Le Maitre, D.C., Gaertner, M., Marchante, E., Ens, E.J., Holmes, P.M., Pauchard, A., O’Farrell, P.J., Rogers, A.M., Blanchard, R., Blignaut, J. \& Richardson, D.M. (2011)
Impacts of invasive Australian acacias: implications for management and restoration. Diversity and Distributions, 17, 1015-1029.

Le Roux, J.J., Brown, G.K., Byrne, M., Ndlovu, J., Richardson, D.M., Thompson, G.D. \& Wilson, J.R.U. (2011) Phylogeographic consequences of different introduction histories of invasive Australian Acacia species and Paraserianthes lophantha (Fabaceae). Diversity and Distributions, 17, 861-887.

Marques, M.S., Pagano, M. \& Scotti, M.R.M.M.L. (2001) Dual inoculation of a woody legume (Centrolobium tomentosum) with rhizobia and mycorrhizal fungi in south-eastern Brazil. Agroforestry Systems, 52, 107-117.

Menna, P. \& Hungria, M. (2011) Phylogeny of nodulation and nitrogen-fixation genes in Bradyrhizobium: supporting evidence for the theory of monophyletic origin, and spread and maintenance by both horizontal and vertical transfer. International Journal of Systematic and Evolutionary Microbiology, 61, 3052-3067.

Menna, P., Hungria, M., Barcellos, F.G., Bangel, E.V., Hess, P.N. \& Martínez-Romero, E. (2006) Molecular phylogeny based on the 16S rRNA gene of elite rhizobial strains used in Brazilian commercial inoculants. Systematic and Applied Microbiology, 29, 315-332.

Moulin, L., Munive, A., Dreyfus, B. \& Boivin-Masson, C. (2001) Nodulation of legumes by members of the $\beta$-subclass of Proteobacteria. Nature, 411, 948-950.

Moulin, L., Béna, G., Boivin-Masson, C. \& Stepkowski, T. (2004) Phylogenetic analysis of the symbiotic nodulation genes support vertical and lateral gene co-transfer within the Bradyrhizobium genus. Molecular Phylogenetics and Evolution, 30, 720-732.

Parker, M.A. (2001) Mutualism as a constraint on invasion success for legumes and rhizobia. Diversity and Distributions, 7, 125-136.

Parker, M.A., Malek, W. \& Parker, I.M. (2006) Growth of an invasive legume is symbiont-limited in newly occupied habitats. Diversity and Distributions, 12, 563-571.

Parker, M.A., Wurtz, A.K. \& Paynter, Q. (2007) Nodule symbiosis of invasive Mimosa pigra in Australia and in ancestral habitats: a comparative analysis. Biological Invasions, 9, 127-138.

Porter, S.S., Stanton, M.L. \& Rice, K.J. (2011) Mutualisms and adaptive divergence: co-invasion of a heterogenous grassland by an exotic legume rhizobia symbiosis. PLoS ONE, 12, e27935.

Posoda, D. \& Crandall, K.A. (1998) MODELTEST: testing the model of DNA substitution. Bioinformatics, 14, 817-818.

Reinhart, K.O. \& Callaway, R.M. (2006) Soil biota and invasive plants. New Phytologist, 170, 445-457.

Richardson, D.M., Allsopp, N., D’Antonio, C.M., Milton, S.J. \& Rejmánek, M. (2000) Plant invasions - the role of mutualisms. Biological Reviews, 75, 65-93.

Richardson, D.M., Carruthers, J., Hui, C., Impson, F.A.C., Robertson, M.P., Rouget, M., Le Roux, J.J. \& Wilson, J.R.U. (2011) Human-mediated introductions of Austra- 
lian acacias - a global experiment in biogeography. Diversity and Distributions, 17, 771-787.

Rodríguez, H. \& Fraga, R. (1999) Phosphate solubilizing bacteria and their role in plant growth promotion. Biotechnology Advances, 17, 319-339.

Rodríguez-Echeverría, S. (2010) Rhizobial hitchhikers from Down Under: invasional meltdown in a plant-bacteria mutualism? Journal of Biogeography, 37, 1611-1622.

Rodríguez-Echeverría, S., Chrisóstomo, J.A., Nabais, C. \& Freitas, H. (2009) Belowground mutualists and the invasive ability of Acacia longifolia in coastal dunes of Portugal. Biological Invasions, 11, 651-661.

Rodríguez-Echeverría, S., Le Roux, J.J., Chrisóstomo, J.A. \& Ndlovu, J. (2011) Jack-of-all-trades and master of many? How does associated rhizobial diversity influence colonization success of Australian Acacia species. Diversity and Distributions, 17, 946-957.

Romdhane, S.B., Nasr, H., Samba-Mbanye, R., Neyra, M. \& Ghorbal, M.H. (2005) Diversity of Acacia tortilis rhizobia as revealed by PCR/RFLP on crushed root nodules in Tunisia. Annals of Microbiology, 55, 249-258.

Ronquist, F. \& Huelsenbeck, J.P. (2003) MrBayes 3: Bayesian phylogenetic inference under mixed models. Bioinformatics, 19, 1572-1574.

Slabbert, E., Kongor, R.Y., Esler, K.J. \& Jacobs, K. (2010) Microbial diversity and community structure in Fynbos soil. Molecular Ecology, 19, 1031-1041.

Swofford, D.L. (2002) PAUP*: phylogenetic analysis using parsimony ( ${ }^{*}$ and other methods). Version 4. Sinauer Associates, Sunderland, MA.

Sy, A., Giraud, E., Jourand, P., Garcia, N., Willems, A., de Lajudie, P., Prin, Y., Neyra, M., Gillis, M., Boivin-Masson, C. \& Dreyfus, B. (2001) Methylotrophic Methylobacterium bacteria nodulate and fix nitrogen in symbiosis with legumes. Journal of Bacteriology, 183, 214-220.

Tan, Z.Y., Kan, F.L., Peng, G.X., Wang, E.T., ReinholdHurek, B. \& Chen, W.X. (2001) Rhizobium yanglingense sp. nov., isolated from arid and semi-arid regions in China. International Journal of Systematic and Evolutionary Microbiology, 51, 909-914.

Thompson, J.D., Higgins, D.G. \& Gibson, T.J. (1994) CLUSTAL W: improving the sensitivity of progressive multiple sequence alignment through sequence weighting, position-specific gap penalties and weight matrix choice. Nucleic Acids Research, 22, 4673-4680.
Veena, K. \& Poonam, S. (2011) Potential for enhancing lentil (Lens culinaris) productivity by co-inoculation with PSB, plant growth-promoting rhizobacteria and Rhizobium. The Indian Journal of Agricultural Sciences, 81, 932-934.

Versalovic, J., Schneider, M., de Bruijin, F.J. \& Lupski, J.R. (1994) Genomic fingerprinting of bacteria using repetitive sequence-based polymerase chain reaction. Methods in Molecular and Cellular Biology, 5, 25-40.

Vincent, J. (1970) A manual for the practical study of the root-nodule bacteria. IBP 32 Handbook No. 15. Blackwell, Oxford.

Wei, G., Chen, W., Zhu, W., Chen, C., Young, J.P.W. \& Bontemps, C. (2009) Invasive Robinia pseudoacacia in China is nodulated by Mesorhizobium and Sinorhizobium species that share similar nodulation genes with native American symbionts. FEMS Microbiology Ecology, 68, 320-328.

Weir, B.S., Turner, S.J., Silvester, W.B., Park, D.C. \& Young, J.M. (2004) Unexpectedly diverse Mesorhizobium strains and Rhizobium leguminosarum nodulate native legume genera of New Zealand, while introduced legume weeds are nodulated by Bradyrhizobium species. Applied Environmental Microbiology, 70, 5980-5987.

Weisburg, W.G., Barns, S.M., Pelletier, D.A. \& Lane, D.J. (1991) 16S ribosomal DNA amplification for phylogenetic study. Journal of Bacteriology, 173, 697-703.

Wilkinson, H.H. \& Parker, M.A. (1996) Symbiotic specialization and the potential for genotypic coexistence in a plant-bacterial mutualism. Oecologia, 108, 361-367.

\section{BIOSKETCH}

Joice Ndlovu is a doctoral student at the DST-NRF Centre of Excellence for Invasion Biology at Stellenbosch University (CIB; http://academic.sun.ac.za/cib/). She is interested in plant microbial interactions, particularly how plant microbial symbionts facilitate plant invasions.

Author contributions: All authors conceived the ideas; J.J.LeR. and J.N. collected the data; J.N. analysed the data; and J.N. and J.J.LeR. led the writing.

Editor: Pauline Ladiges 